\title{
Archipel
}

ARCHIPEL Études interdisciplinaires sur le monde insulindien

Hors-Série $n^{\circ} 2$ - Patani Through Foreign Eyes: Sixteenth And Seventeenth Centuries (Edited By Daniel Perret \& Jorge Santos Alves) | 2022

Patani Through Foreign Eyes: Sixteenth And

Seventeenth Centuries

\section{A. Patani and the Luso-Asian Networks (1516-1642)}

Jorge Santos Alves

\section{(2) OpenEdition \\ Journals}

Electronic version

URL: https://journals.openedition.org/archipel/2799

DOI: 10.4000/archipel.2799

ISSN: 2104-3655

Publisher

Association Archipel

\section{Printed version}

Date of publication: 28 February 2022

ISBN: 978-2-910513-88-7

ISSN: 0044-8613

Electronic reference

Jorge Santos Alves, "A. Patani and the Luso-Asian Networks (1516-1642)", Archipel [Online], Hors-Série $n^{\circ} 2$ - Patani Through Foreign Eyes: Sixteenth And Seventeenth Centuries (Edited By Daniel Perret \& Jorge Santos Alves) | 2022, Online since 28 February 2022, connection on 18 March 2022. URL: http:// journals.openedition.org/archipel/2799; DOl: https://doi.org/10.4000/archipel.2799 


\title{
A. Patani and the Luso-Asian Networks (1516-1642)
}

\author{
JORGE SANTOS ALVES
}

Ever since the late fifteenth century, the port of Patani has featured on the maps of Asian maritime trade. This position steadily advanced under the protective benevolence of Siam to become a commercial pole in the multiple connections between Southeast Asia and the Chinese markets. Its strategic position, a sheltered port halfway between Java and China, attracted Asian investors and traders from various backgrounds (Chinese, Javanese, Malay, Thai, among others). Patani competed with the other ports on the Malay Peninsula (such as Pahang), but above all with those in the Straits of Malacca, such as Malacca itself, for the trade in Chinese products (like porcelains, silks or lacquers) exchanged for clove and nutmeg from Maluku, sandalwood from Timor, and especially pepper from the Malay Peninsula, Sumatra and Java. ${ }^{1}$ Gradually, over the early years of the sixteenth century, Patani became home to an expanding community of overseas Chinese, many of whom first installed their vessels there before following with their own residences and livelihoods. On occasion dedicated to illegal trading activities with China, on others, they became privateers or pirates. The commercial and financial development of Patani would nevertheless seem to have gone relatively unnoticed by the new players and the first Europeans in the region - the Portuguese.

\footnotetext{
* Instituto de Estudos Asiáticos/Institute of Asian Studies, Universidade Católica Portuguesa, Lisbon.

1. On the "founding" and development of Patani as an international trading port between the fifteenth and seventeenth centuries, see Perret (2004: 18-36; 223-226).
} 


\section{Peace and War: Sultan Ismail Syah and Portuguese Malacca (1516-1533)}

After taking Malacca in 1511, the Portuguese defined their priorities as establishing strategic local and regional partnerships with Siam, Pegu, Java and China. Patani remained, almost naturally, marginal to Portuguese interests and broadly off its diplomatic and commercial radar. It was courtesy of King Manuel (1491-1521) defining means of making diplomatic and commercial approaches to Ming China that, after 1515, Patani entered, also almost naturally, onto the Portuguese political-diplomatic agenda for Southeast Asia and the China Sea. ${ }^{2}$

Hence, in late 1516, while making his way to southern China and accompanying the first Portuguese and European embassy to the Ming dynasty, Fernão Peres de Andrade made a stopover in the port of Patani. João de Barros, an official Portuguese chronicler, was very explicit about this choice: "the Port of the city of Patani [...] where there gathers many of the vessels of China, Ryukyu, and Java, and all those other neighbouring islands, as it handles a very well reputed trade [...]." ${ }^{3}$

We do not know whether the Sultan of Patani and his predominantly Chinese mercantile elite, held any real interest in the Portuguese agenda as represented by Peres de Andrade and Tomé Pires, who accompanied him as ambassador of the King of Portugal to the Chinese Emperor Zhengde (15061521). ${ }^{4}$ It is also João de Barros (and only him) who informs us how Peres de Andrade arrived at some kind of understanding ("assentou paz" - "settled the peace") with "the Governor of the land." Is Barros here referring to Sultan Ismail Syah (?-1524/1530?)? Or is he instead following the usual patterns in Portuguese sixteenth century sources on maritime Southeast Asia that, whenever referring to the "governor," he is in fact making reference to the bendahara or to the syahbandar? Whatever the answer might actually be, the agreement reached between the authorities in Patani and the Portuguese provided authorisation for Portuguese vessels to trade in this port and Patani vessels to trade in Malacca. Immediately taking advantage of this opportunity was the controversial Captain of Malacca, Jorge de Brito (1515-1517), who sent ships to trade in Patani in that same year. ${ }^{6}$ In addition to Brito, other Portuguese privateers began to trade in Patani, always with the Chinese

2. It is significant that the Suma Oriental by Tomé Pires (written in Malacca between 1512 and 1515), contains only some sparse and brief references to Patani and does not have a specific entry on the sultanate as happens with the majority of the other states and polities in the region.

3. Barros: III/2/6.

4. On the embassy of Tomé Pires to Ming China, see Alves (2018: 27-49).

5. Barros: III/2/6.

6. Idem. 
market in their sights and probably interconnected with the Chinese interests and capital in Patani (perhaps also Malacca?). During these years, Sultan Ismail Syah of Patani was himself investing in trading with China, sending at least one of his junks to Guangzhou. ${ }^{7}$ There are reports from 1521 of the presence of Portuguese on Chinese junks arriving in Guangzhou from Patani as was the case with Bartolomeu Soares, who would arrive along with the ships captained by Francisco Rodrigues and Jorge Álvares ${ }^{8}$ who had been the first Portuguese visitor to China in 1513.

In Patani, the Chinese community was already substantial and numerous by the early sixteenth century, deeply involved in the trade ongoing with the coasts along Southern China as well as with Siam, Malacca and probably Pahang. The Xu family was leading in this community. The Xu brothers, magnates in the trade between Southeast Asia and China, were originally from Huizhou, in Guangdong province. They had already accumulated years of contacts and partnerships with various Asian commercial operators across the region, as well as with the Portuguese at least since 1509. ${ }^{9}$ One of these Cantonese brothers, $\mathrm{Xu}$ Dong or Xu Er (thus, the "Second Xu"), while having already spent time in Patani for some years, took up more permanent residence there in 1526 while turning it into the base for his commercial operations. ${ }^{10}$ Patani had become so attractive to the Chinese that it was the natural destination for the Chinese crew of a Malay (?) junk that departed Guangzhou with a message from Emperor Jiajing to the Sultan of Malacca, then exiled in Bintan, in 1523. ${ }^{11}$

To a certain extent, the Chinese were also involved in the changes that occurred in the relationship between Patani and the Portuguese of Malacca in 1523. The Hikayat Patani totally omits any reference to this period in the political history of the sultanate. However, it suggests that the reign of Sultan Ismail Syah saw the access of Patani to military technology capable of casting heavy artillery. This all stemmed from a technology transfer that involved a Chinese trader and a Turk/Rumi counterpart (Abdul Samad). ${ }^{12}$

7. In 1521, at least one of the Sultan of Patani's junks had joined a fleet coming from Siam and was seized by the Chinese imperial navy off the coasts of Guangdong (Cativos Cantão: 32). The information in this document is however confusing; further along, it advances the claim that a total of three of the Sultan's junks were seized by the Chinese authorities.

8. Cativos Cantão: 32.

9. On the first Luso-Chinese commercial partnerships, see Alves (2007: 13-15). A biographical note on Xu Lada, or Xu Nan ("Third Xu") can be found in Alves (2003: 326-328). We are grateful to Jin Guoping and James K. Chin for the information referencing the Chinese sources on this Chinese magnate.

10. Chin 2009: 124-125.

11. Cativos Cantão: 37 (see document 1).

12. $H P T \& W$ : II, 152-154. For the same period (between 1522 and 1525), we have another case of the early local casting of artillery in Panarukan (Java), also due to the 
Equipped with artillery even if still rudimentary, Patani would now seem able to assume another level of importance in the ongoing geopolitics of the region and capable of allying with other regional powers, such as Bintan where the former Sultan of Malacca ruled - and Pahang. This alliance would seem to have sought to challenge the Portuguese presence both in Malacca and in the broader region of the Straits and the Malay Peninsula in the early years of the 1520s. Pressured by this new regional situation, the Captain of Malacca, Jorge de Albuquerque (1521-1525), was forced into requesting military assistance from Goa, the seat of the Portuguese Estado da Índia. The motive was an uprising in Pahang (curiously referred to as "Pahang in China"), which was threatening to send an armada of junks (Chinese?) against Malacca. ${ }^{13}$ Also in 1523, and seriously worsening the difficulties of the official Portuguese presence in Southeast Asia, came the loss of the fortress/ factory in the pepper port of Pasai, on the northern reaches of Sumatra. This was a heavy blow to Portuguese interests. Pasai was one of the pillars in the Portuguese triangular strategy (Malacca-Pasai-Guangzhou) to access Chinese markets and represented the key port for the supply of pepper to Portuguese vessels bound for China. ${ }^{14}$ The defeat and expulsion of the Portuguese and their local and international allies in Pasai as a consequence of the politicalmilitary expansionism of the Sultanate of Aceh, a rising star among the Malay sultanates of the Malacca Strait, meant the temporary closure of access to pepper supplies destined for China. This event threatened the survival of Portuguese trade in Malacca as well as the life in the city itself, especially due to the lack of supplies and provisions (particularly rice). Pahang seized Portuguese vessels in its port and killed their crews, Bintan laid siege to Malacca and Patani closed off its supply of provisions and goods. The new Patani policy, apparently in coalition with Bintan and Pahang, combined with the expansionism of Aceh, forced Jorge de Albuquerque into desperate

influence of experts who probably originated from the Middle East or the Near East (Alves 2007: 13-14). In this case, it would seem that the cannons were imitations of Portuguese artillery. Would this also hold for the case of Patani? In 2008, the Thai mega-production Queens of Langkasuka (from the original title after (before?) censorship, Queens of Pattani) by Nonzee Nimibutr, has a plot structured around a large calibre cannon cast by a Dutch and a Chinese during the reign of Raja Hijau, and the battle against an usurper allied to a powerful group of pirates.

13. Instruction from Jorge de Albuquerque to Bastião de Sousa, Malacca, 14/12/1523, ANTT, Corpo Cronológico, I-30-72 (Thomaz 1964, II). The Malacca agreement with Pahang was negotiated by Martim da Rocha in the name of the King of Portugal in 1520 . Rocha was accompanied by a committee of Chinese traders who provided assistance in the negotiations. In fact this agreement never came into effect (Instruction from Garcia de Sá to Martim da Rocha to establish peace with the king of Pahang, Malacca, 15/4/1520, ANTT, CC, I-27-88, fl. 2) (Alves 1991: II, 44-47).

14. On this matter, see Alves (1999: 55-63). 
measures. In order to prevent Malacca becoming isolated, Albuquerque issued an emergency plea to Goa calling for military reinforcements. In 1524, Goa dispatched a small armada led by Martim Afonso de Sousa, a veteran of the naval war in Kerala and Ceylon. Unaware of the local conditions, impatient and pressured by the private Portuguese interests in Malacca, Sousa launched naval attacks on Bintan, Kelantan, Pahang and Patani in June 1524, without even awaiting for - or perhaps running counter to - orders from the Captain of Malacca. ${ }^{15}$ This assault hit Patani harshly. The Martim Afonso de Sousa armada, after destroying various Asian trading vessels in the Strait of Malacca as reprisals for the seizure of Portuguese vessels and the death of their crews, headed onto Patani. Here, Sousa wrought tremendous destruction: he burned or sank 36 (Chinese?) junks, assailed and burned down the city. Throughout the following two weeks, he anchored in the port, capturing and destroying another 70 junks arriving from Siam and Java. ${ }^{16}$ This impressive number of junks, whether already in the port or on route to Patani from China, Siam and Java, reflects the exponential growth of the city within the framework of regional and international trade.

Various Portuguese sources related to this Portuguese attack of June 1524 put forward some very relevant information about Patani. Firstly, they provide details on the city itself, made up of constructions in wood, stone and brick ${ }^{17}$ demonstrating the highly visible extent of its growth. Secondly, they tell us that, in addition to the city, the Portuguese also torched the dusun, fully aware of the importance of this transition zone between the coastline and the hinterland that included plantations ("ortas" - orchards - and "palmares" palm groves) of high relevance to secure food supply for Patani itself, and probably including cash crops for export. ${ }^{18}$

Other important information directly relate to the Sultan of Patani, even if in very contradictory terms. Some Portuguese texts recount how, on his arrival from Java in a (Javanese?) junk, Sultan Ismail Syah was captured in this Martim Afonso de Sousa's attack, and then executed alongside several hundred individuals. ${ }^{19}$ Other sources mention that the sultan escaped death because he was in Siam at the time, on a tributary visit to King Ramathibodi II (14911529). ${ }^{20}$ The latter may be the true scenario as no Portuguese sources (nor Malay) mention about a new sultan taking power at that time. Also uncertain is when,

15. Barros: III/10/2; Letter from Pedro de Mascarenhas to the King of Portugal, Malacca, 1/9/1525, ANTT, CC, I-32-106, fl. 2v (published as document 4).

16. Lembrança 1525: 7; see also, although without any numbers: Barros, III/10/2; Correia, II, 779, 800; Castanheda, II, 248.

17. Correia: II, 800. An excerpt of this Portuguese source is published as document $\mathrm{n}^{\mathrm{0}} 2$.

18. Correia: II, 800; Castanheda: II, 248-249.

19. Correia: II, 800; Castanheda: II, 248.

20. Lembrança 1525: 7; Barros: II/10/2. 
early in the following year (1525), the Portuguese sought to reopen a diplomatic channel with Patani. Moreover the extent of the destruction caused by June 1524 attack still remains to be ascertained and, more importantly, how quickly the reconstruction of the city and the restoration of its commercial life took place.

We are on firmer ground to state that the new Captain of Malacca, Pedro de Mascarenhas (1525-1526), opted in favour of re-connecting with Patani. He sent an armada against Pahang, led by Martim Afonso de Melo Jusarte, but also dispatched a mission to Patani in August 1525. ${ }^{21}$ Its main objective was to guarantee the supply of food and provisions (especially rice) to Malacca, which might suggest that the Patani economic and commercial life quickly recovered, at least partially. At first, the diplomacy did not work out, perhaps because the Portuguese attack was still too fresh in the minds of the sultan and the population. This initial failure led Melo Jusarte to order the seizure of at least 16 junks (local and international) anchored in the port. ${ }^{22}$ Pressured by these events and, perhaps thanks to the mediation of Tun Muhammad, a Luzon trader, ${ }^{23}$ who accompanied the Portuguese, the sultan (still Ismail Syah?) reached a peace agreement with the Portuguese and committed to the sending of substantial supplies and provisions to Malacca. ${ }^{24}$

On the ground, this agreement was a success for the "frontier" diplomacy of Malacca. Within the general framework of the foreign policy of the Portuguese Estado da Índia, it was the result of the new official Portuguese policy towards Pahang and Patani, a facet of the "China policy" of the King of Portugal. After the setbacks and confrontations off the coastline of Guangdong in 1520 and 1522, King João III (1521-1557) again turned towards China. However, this time, his perspective was more pragmatic and moderate, without the conquistador attitude and militaristic spirit of King Manuel. He set this down openly in the written instructions dispatched in 1526 to Pedro de Mascarenhas,

21. Letter from Pero de Mascarenhas to the King of Portugal, Malacca, 1/9/1525, fl. 2v; Letter from Martim Afonso de Melo Jusarte to the King of Portugal, Malacca, 28/8/1525, ANTT, CC I-32-101.

22. Correia: II, 937; Castanheda: II, 314. The excerpt of Gaspar Correia's book is published as document $\mathrm{n}^{\circ} 3$.

23. Letter from Pero de Mascarenhas to the King of Portugal, Malacca, 1/9/1525, fl. $2 \mathrm{v}$. An excerpt of this letter is published as document $\mathrm{n}^{\circ} 4$. Tun Muhammad was a Luzon trader, son of the magnate Arya Rana Adiraja, from whom he inherited the office of temenggong in Malacca by late 1513. As did his father, he maintained trading interests with China and owned a Chinese junk that he also inherited. He collaborated very closely with the Portuguese in defence of Malacca on more than one occasion. In 1517, he managed two junks in partnership with his mother, Tun Doyam. For further details on this trader and other individuals from the Luzon community living in Malacca, as well as its China connections in the later period of the Malay sultanate and the early years of the Portuguese conquest, see Alves (2003).

24. Correia: II, 937; Castanheda: II, 314. 
then still Captain of Malacca but already nominated as Governor of the Estado da Índia. King João III pragmatically recommended a re-connection with China while maintaining good contacts with those "lands in the kingdom of Siam and those of Patani and the others with which they [the Chinese] now do trade, sending to them my message and showing to them all my desire to achieve a manner in which you shall be able to work in order to bring about trade and based on peace and friendship." 25

Patani was a key place, especially after the loss of influence in Pasai and the failed attempt to enter the pepper market in Sunda (West Java) in 1522, in order to obtain Southeast Asian spices and drugs to prepare for an eventual return to the Chinese market or even to deal directly with the Chinese junks that would pass through Malacca. Nevertheless, Patani remained free of the Portuguese military-naval and diplomatic pressure and was highly active in international markets. We know that Patani junks were trading in Banda (certainly for nutmeg and mace) in $1525^{26}$ and that in late 1526/1527 at least 30 Chinese junks from Fujian (Quanzhou and Zhangzhou) arrived in various Southeast Asian ports, including Pahang and Patani. ${ }^{27}$

Chinese sources highlight 1526 as the year which saw the expansion of the Chinese overseas community in Patani. In fact, one of the Xu brothers already mentionned above was an old associate of the Portuguese in the region. Originally from Guangdong (precisely from Huizhou, in the Pearl River Delta), Xu Dong (or Xu Er, thus the second brother) took up residence in Patani in 1526 before marrying a local woman. Xu Dong was accompanied by two brothers (Xu Song and Xu Zi), while another brother, Xu Nan, settled in Malacca. ${ }^{28}$ In fact, Xu Dong brought his entire operational structure with him to Patani, which included a fleet made up of various junks and their respective crews (and their families?), as well as their captains and associates. Li Guangtou, ${ }^{29}$ another Cantonese trader and old partner of $\mathrm{Xu}$, might have been among them. In fact, looking at the importance of this operational structure, the framework was probably a kind of multinational corporation that included partnerships with Luzon traders (such as Arya Rana Adiraja) and Tamil merchants (such as Nayinar Suryadevan). Lin Jiang, another magnate and Chinese smuggler, perhaps also Cantonese, and another partner of $\mathrm{Xu}$

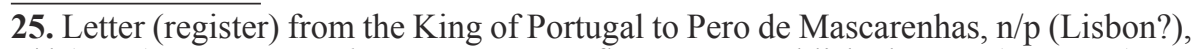
n/d (1526), ANTT, Fundo Antigo, no 875, fls. 71v-72, published Costa (1996: 82).

26. Correia: II, 885.

27. Letter from Jorge Cabral to the King of Portugal, Malacca, 10/9/1527, ANTT, CC I-22-80, in Alves (1991: II, 101-120 [117]).

28. On this family of Chinese smugglers, sometimes also pirates, see Chin (2009: 124126). For further details on their partnership with the Portuguese, see Alves (2003: 326-328).

29. Chin 2009: 125 . 
Dong, resided in Pahang. Chinese sources mention that he became the leader of the Chinese community there from the beginning of the sixteenth century. The prosperity of Lin reached such a scale by the 1540 s that he was running a fleet of more than 70 junks. ${ }^{30}$ The truce between Patani and Malacca ensured the return of various junks loaded with supplies and Chinese goods to the Portuguese-dominated city in $1527 .{ }^{31}$

However, political, diplomatic and economic relations still had to wait for normalisation with Patani and especially with China. Perhaps this awaited the coming to power of a new sultan to succeed Ismail Syah. Sources known so far, whether local or foreign, are silent about the exact date and circumstances of the royal succession in Patani. ${ }^{32}$

\section{The Gama Effect - Patani and Portuguese Trade in China (1533-1554)}

Whether or not Sultan Ismail Syah was still ruling Patani, the fact remains that relations with the Portuguese of Malacca underwent new developments in the early 1530s. They were initiated by Paulo da Gama (1533-1534), who was then inaugurating an almost two-decade-long period of Gama family control over both the captaincy of Malacca and the Portuguese trade with China. We here refer to the children of Vasco da Gama, the Portuguese "hero" of its Age of Discoveries. ${ }^{33}$ Despite having barely taken up the position of Captain of Malacca, Paulo da Gama dispatched a mission which would nowadays be termed as "economic diplomacy" to the neighbouring sultans of Pahang and Patani. The Patani mission was led by Manuel Godinho and turned out particularly successful..$^{34}$ This proved so much the case that when his brother, Estevão da Gama, succeeded him as Captain of Malacca in 1534, he was also able to take advantage of - and perhaps he was already aware of this before his departure from Goa - the exceptional commercial conditions that had been made possible by the return of the Portuguese to the Chinese markets, via Patani (and Pahang). Strangely enough, nothing transpired for Goa or Portugal as a consequence of this mission and its results. In fact, it was only twelve years after these events and, one could say by pure chance, that information about this mission emerged thanks to a letter of services authored by Manuel Godinho. It implies that no information circulated, via official or non-official channels, to Goa or to Portugal, about the sensational outcome of the mission

30. Chin 2009: 125-126.

31. Letter from Pero Barriga to the King of Portugal, Malacca, 3/8/1527, in Alves (1991: II, 81-93 [92]).

32. $H P T \& W: 3-9,11$.

33. On Vasco da Gama, the Gama family and their historical heritage, see Subrahmanyam (1998).

34. Manuel Godinho to the King of Portugal, Goa, 25/10/1545, ANTT, CC I-76-118, published in Alves (1999: 261-268 [266]); Correia: III, 487. 


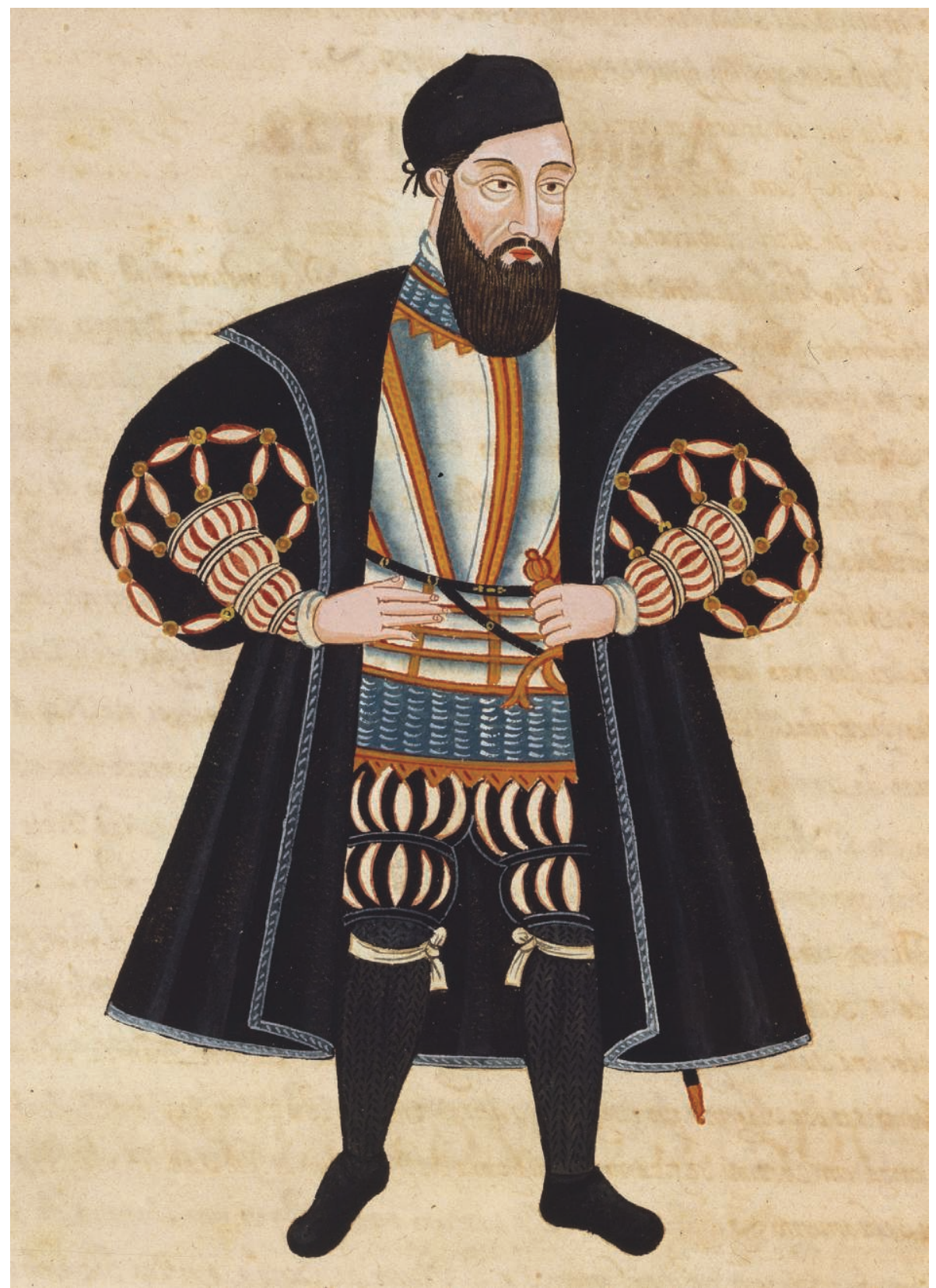

Estêvão da Gama, Governor of the Estado da India (1540-1542), in Pedro Barreto de Rezende, Relacion da India, 17th cent., Department of Manuscripts (Portugais 1), Bibliothèque Nationale de France. 
headed by Godinho in Patani. One can wonder whether the Gama brothers, first Paulo and then Estêvão, deliberately kept this news of the reopening of China to Portuguese commercial contacts under wraps.

If so, this might indicate how Estêvão da Gama would have found, upon his arrival in Malacca in 1534, the embryo of a commercial network that had already been established by his brother Paulo, who also remained in the city - with the office of captain-major of the sea of Malacca - until his death later that year. ${ }^{35}$ In any case, it is clear that the preservation of a certain degree of discretion as regards the exploration of the routes to the markets of South China was of vital importance for the Gama family and the key to the success of their private trading network. One can therefore also understand their prudent silence about the fundamental role played by the port of Patani. It was precisely Patani, and not Malacca, that was the centre of the mercantile operations of Estêvão da Gama's network during his time as Captain of Malacca. Once again, it was only years after his departure from Malacca, as explained below, that one can penetrate the barrier of silence that surrounds the commercial activities of the Gama family in Patani.

As Captain of Malacca (1534-1539), Estêvão da Gama built up a complex and highly profitable network that included various Portuguese and Asian participants. On the Asian side, always in relation to Patani, a single name entered the inner circle of this network: a Malacca-born rich Tamil merchant called Nayinnar Melaka. ${ }^{36}$

Estêvão da Gama's commercial network was located in Pahang ${ }^{37}$ and, above all, in Patani, ${ }^{38}$ which is quite understandable as they were privileged ports for trade with South China where a large part of the investments of this Captain of Malacca were directed. Estêvão da Gama always sent his goods to

35. It is also possible that the appointment, in 1538, of another brother of Estêvão and Paulo da Gama, Cristóvão da Gama, to the captaincy of Malacca, could likewise have been part of this strategy by the da Gama family (Letter of appointment of Cristóvão da Gama to the captaincy of Malacca, Lisbon, 12/1/1538, ANTT, Chancelaria de D. João III, book 49, f. 39v), published in Thomaz (1964: II, 295-296).

36. This Tamil magnate was appointed syahbandar of Malacca by Estêvão da Gama upon his arrival, thus ousting from his post the holder of this office at the time, the Malay Tun Muhammad (Alves 2003: 315). To all appearances, Nayinnar Melaka was the main agent in Estêvão da Gama's network that, moreover, favoured contacts with the city's Tamil community. It was rumoured, something not denied by Estêvão da Gama, that the Tamil magnate was entrusted with channelling the goods and capitals of the network towards the ports of the Malay Peninsula (especially Patani). From there, they were channelled towards the Chinese markets in association with overseas Chinese (Letter from Pero de Faria to the King of Portugal, Malacca, 23/11/1540), cited above; Letter from Estêvão da Gama to the King of Portugal, n/d (Goa, post1542), ff. 1v, 2, 3v, published as document no.8).

37. Castanheda: II, 699.

38. Idem. 
China via Patani, where his factor would despatch them aboard junks owned by overseas Chinese. In addition, he would charge Portuguese traders resident in Malacca an additional transit tax to carry their merchandise to Patani, from where they would later be carried in Chinese junks to South China ports. ${ }^{39}$

Moreover, with regard to Patani, Estêvão da Gama apparently charged Malay and Tamil merchants based in Malacca a fee for providing a military escort to their ships, which crossed the Straits en route to Patani ${ }^{40}$ Albeit limited, the available data reveal the intensity of the activities of this network orientated toward the Chinese markets between 1534 and 1541. There is evidence to corroborate the undertaking of at least four voyages made under Estêvão da Gama's aegis, all of them with either a departure point from or passage through Patani: Manuel Botelho in $1534^{41}$; Rui Lobo, with one or perhaps more voyages until his death in Ningbo in 1538 ${ }^{42}$; Cristóvão Sardinha and his associate the Armenian Tomé "Mustangue" in the junk of the Muslim Chinese trader Kiai Taijun (who dubbed himself "Kapitan Sardinha" - or "Captain Sardine"), in 1538/153943; and Manuel de Brito in 1540/1541. ${ }^{44} \mathrm{We}$ do not include here the voyage to China that was promised and later denied to Diogo Nunes, departing from Patani, where he had taken on a cargo of pepper, perhaps in $1539 .{ }^{45}$ In this case, Estêvão da Gama prohibited the departure of the junk (Chinese) that was to sell both to Nunes and to their factors in Patani (João Ribeiro and Lopo Vaz Camelo) but he also denied permission for loading the junk with pepper for China. ${ }^{46}$

Estevão da Gama ruled the commercial operations with an iron fist and enjoyed the exclusivity on trade with Chinese ports out of Patani to the extent that, in 1534, he dispatched a man in his trust and a vital member of his business network, Francisco de Barros de Paiva, ${ }^{47}$ on a diplomatic mission to the Sultan

39. Letter from Estêvão da Gama to the King of Portugal, n/p (Goa), n/d (post-1542), f. 8. 40. Idem, f. 7.

41. Letter from Pero de Faria to the King of Portugal, Malacca, 23/11/1540, cited above.

42. Pinto Peregrinação: 142-143.

43. Pinto Peregrinação: 119-120.

44. Pero de Faria to the King of Portugal, Malacca, 23/11/1540, cited above; Correia: II, 563.

45. Letter from Pero de Faria to the King of Portugal, Malacca, 22/11/1540, As Gavetas, V, 26-31 [26].

46. Letter from Diogo Nunes to the Governor of the Estado da Índia, n/p (Malacca), n/d (post-1540), ANTT, Fragmentos, caixa 13, maço 13, doc. 29, fl. 1.

47. Francisco de Barros de Paiva was a Portuguese nobleman (fidalgo) very much involved in maritime war off the Kerala Coast, in the Straits of Malacca. In 1538 he joined the Portuguese embassy to the sultan of Bengal. 
of Patani (as well as his cousin Simão Sodré ${ }^{48}$ to the Sultan of Pahang) ${ }^{49}$ His mission involved confirming the willingness of the sultan (already Mudhaffar Syah?) to maintain peace with Malacca and guarantee the flow of trade to the Chinese market. The signs would seem to have been positive, but Barros de Paiva and the Gama network still had to face another threat to their business: the raids of the Javanese "corsairs" along the east coast of the Malay Peninsula, especially in the areas around Pahang and Patani.

Whether this Javanese pressure already existed prior to the mid-1530s due to new circumstances or whether it simply passed unnoticed by Europeans/ Portuguese, still remains to be determined. However, that same year 1535, the overseas Portuguese chroniclers unanimously refer to the presence of Javanese fleets in the region. One such armada, with more than twenty large, oar-powered ships, well-equipped with artillery, carrying about 2,000 men, was captained by Arya Kadih (?). ${ }^{50}$ Another, more powerful (with more than 60 vessels), was led by Patih Barah (?). ${ }^{51}$ No precise information is available about the origins of these Javanese fleets, but they were likely drawn from various ports of the Pasisir. ${ }^{52}$

The departure of Estêvão da Gama from Malacca (following his promotion to Governor of the Estado da Índia, 1540-1542) momentarily removed the Gama family from the China via Patani trade. However, a few years later, two others of the Vasco da Gama sons and captains of Malacca, Pedro da Silva da Gama (1548-1552), and Álvaro de Ataíde da Gama (1552-1554), would seek to restore the private Portuguese trading networks with China. ${ }^{53}$

Furthermore, in the $1540 \mathrm{~s}$, another Portuguese and Luso-Asian network maintained close contacts with Patani. It was led by one of the "old Asia hands," Pero de Faria. Faria twice served as Captain of Malacca (1528-1529 and 1539-1542), and in his second tenure in the office succeeded none other than Estêvão da Gama, of whom he was one of the harshest critics of the Malacca captaincy.

48. Simão Sodré was a Portuguese nobleman (fidalgo), a member of the Albuquerque "clan" in Asia (he was nephew of Vasco da Gama). He served the Estado da India in several war scenarios, namely off the West India Coast, the Straits of Malacca, and finally in $1525 / 1526$ in the Maldives.

49. Barros: IV, 9/15; Castanheda: II, 715; Correia: III, 631. The excerpt from João de Barros is published as document $\mathrm{n}^{\circ} 6$.

50. Barros: IV/9/15, calls him "Ericatim"; Castanheda: II, 715, calls him "Eriacatim"; Correia: III, 631 "Fracaria." They all state that he was a Javanese Muslim.

51. Barros: IV/9/15; Castanheda: II, 717; Correia: III, 632.

52. There is a later reference to a Javanese attack on Patani. It is undated, but may have occurred in the 1580s (Gaio Patani, fl. 132). Published as document no. 19.

53. On this point, see Alves (1999: 60-65). 
During this second tenure, Pero de Faria built a well-oiled network of private maritime trade, covering almost all of Southeast Asia and the South China Sea. ${ }^{54}$ Patani played a central role in the commercial operations of this network. To all appearances, the organisation of Pero de Faria's network was based upon a family structure. His Luso-Asian sons played key roles in this activity: Álvaro de Faria ${ }^{55}$ - captain-major of the sea in Malacca during the captaincy of his father and until his death in $1540^{56}$ and, perhaps Vasco de Faria, were the most prominent. ${ }^{57}$ Furthermore, another relative was the António de Faria de Sousa made famous in Peregrinação by Fernão Mendes Pinto. Mendes Pinto himself was a key member of the Pero de Faria network, connecting Kedah, Pahang, Patani, and ports in mainland Southeast Asia (Ayutthaya, Tenasserim and Martaban). ${ }^{58}$ In order to guarantee the security of his commercial operations in Patani, alongside that of the Portuguese community resident there, Faria dispatched Mendes Pinto on a diplomatic mission in 1539 to the sultan, who may be Mudhaffar Syah. In Patani, Mendes Pinto had direct access to the sultan, from whom he secured the safety of the Portuguese trading community in that port. ${ }^{59}$ Another goal of Pinto's diplomatic mission to Patani was to request the intervention of the sultan with the King of Siam to secure the release of a group of Portuguese prisoners held by a Siamese noble, the brother-in-law of the Sultan of Patani. ${ }^{60}$

Mendes Pinto's book reveals that in the late 1530s and early 1540s, there was an approximately 300 individuals strong Portuguese and probably Luso-Asian community living in Patani. ${ }^{61}$ Part of them held strong ties to Malacca, while the

54. For further details on this network, see Alves (2010: 103-109).

55. Pinto Peregrinação: 103.

56. Pero de Faria to the King of Portugal, Malacca, 25/11/1539, IANTT, CC I-66-37, published in Thomaz (1964), II, 305-315 [314]; Pero de Faria to the King of Portugal, Malacca, 22/11/1540, cited above.

57. This Vasco de Faria operated regularly from Patani, en route to China and thereby establishing the triangulation with the ports of Java (Will of António de Faria, Goa, 2/6/1548 (Freitas 1971: 163-168 [164])).

58. In Patani, Mendes Pinto came across João Fernandes Abreu, Lourenço de Góis and Vasco Sarmento, but does not shed any light upon their possible role in Pero de Faria's network (Pinto Peregrinação: 148-149).

59. Pinto Peregrinação: 148-149; Pinto Cartas: 63. Pinto recorded these events in one of his letters dating from 1555, when he was already a Jesuit, about another visit to Patani, during which he was recognised and well received by the sultan. See also Faria e Sousa (III: 51-53) for a slightly different version of these same events, which nevertheless highlights the authority of the sultan over the elites of Patani, especially among anti-Portuguese factions.

60. Pinto Peregrinação: 115. In this reference, Pinto provides a clear description of the matrimonial connections between Patani and Siam that held deep political significance in the mid-sixteenth century.

61. Pinto Peregrinação: 122. 
others commuted between Malacca and Patani. Between 1538 and 1542, this was the case for our already met João Ribeiro (resident factor of Estêvão da Gama's network) and Belchior Pais. ${ }^{62}$ Both individuals maintained good relationships with the overseas Chinese community ${ }^{63}$ that also featured among the associates in the Pero de Faria network. Such associates included: Koja Ali, a Malay from Malacca ${ }^{64}$ who seems to have had family and mercantile ties with the Chinese community in Patani, even with a branch in $\mathrm{Kedah}^{65}$; Nakoda Muhammad, a Chinese Muslim based in Malacca, where he operated in partnership with Tamil and Malay merchants, and with Pero de Faria's network on the Malacca-Martaban route. ${ }^{66}$ Another case was that of the Chinese smuggler called "Quiay Panjão" (maybe a title - Kiai Panjang ${ }^{67}$ or the "Great Venerable One") by Pinto, who explains that he was a well-established individual, with a wife and children in Patani. ${ }^{68}$ This overseas Chinese was possibly originally from Fujian, more precisely from Liaoluo, a bay on the southern shores of the island of Jinmen (Jinmen Dao) ${ }^{69}$ His commercial operations and piracy activities covered Southeast Asia and the Chinese coasts, particularly the provinces of Fujian (he had good guanxi ${ }^{70}$ in Quanzhou), Zhejiang (Ningbo, where he would eventually die) and the Ryukyu Islands - and perhaps in Japan as well. However, the best example would once again be the Xu family that interacted with the Portuguese in general and above all with Pero de Faria, opening up his access to the porcelain production markets

62. Will of Belchior Pais, Malacca, 1/10/1542, Arquivo Histórico da Santa Casa da Misericórdia do Porto, Série H, Banco 6, livro 14, fls. 15-30 [19]. I thank Isabel dos Guimarães Sá for this reference.

63. Villalobos: 177-178.

64. Described by Estêvão da Gama as an "honoured Moor of Malacca" (Estêvão da Gama to the King of Portugal, n/p (Goa?), n/d (post-1542?), cited above, ff. 7v and 8). Koja Ali was executed in 1540 on the orders of the Sultan of Kedah, as a result of the political instability prevailing there at the time.

65. Pinto Peregrinação: 74 . About the few Chinese khojas of Malacca and their ties with the ports in the Strait of Malacca and in China in the late fifteenth and early sixteenth centuries, see Alves (2003: chapter VI).

66. Pinto Peregrinação: 471-473, 480, 482. Nakoda Muhammad always travelled accompanied by one of his sons called "Sepetu" by Pinto.

67. The possible Kiai Panjang title, combining a Javanese element - kiai - and a Malay one - panjang, was not uncommon in maritime Southeast Asia and the South China Sea at the time.

68. Pinto Peregrinação: 186-187.

69. Idem.

70. The Chinese expression guanxi was and remains a core part of doing business in China. It refers to creating a network of personal ties and relationships that can also involve moral obligations and exchanging favours. 
of China. In 1540, one year on from returning to the post of Captain of Malacca, he placed an order for Chinese porcelain in his own name, thus becoming the first European to do $\mathrm{so}^{71}$ but always in connection with the port of Patani. ${ }^{72}$

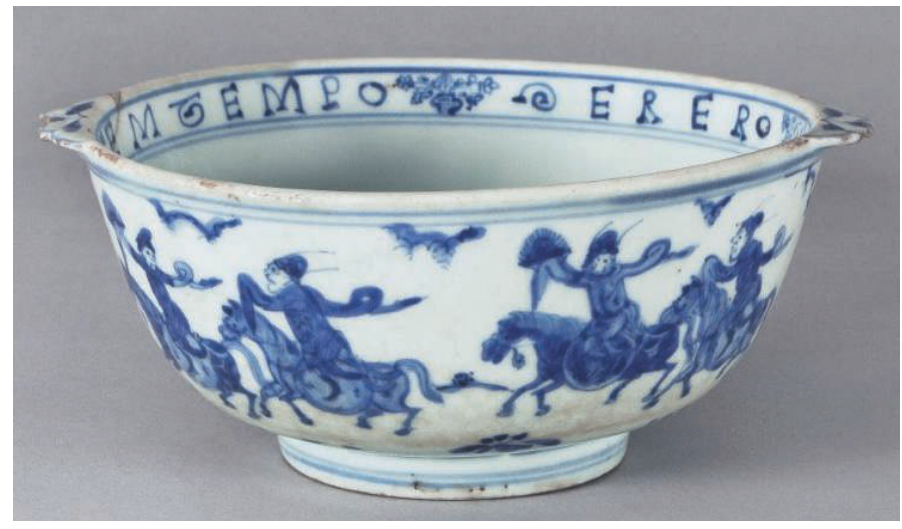

Porcelain bowl "Pero de Faria" (1541), Jiajing Period, Museu Rainha Dona Leonor/António Cunha, Beja, Portugal (inv. PI ST/2)

The major change in the relationship between Patani and the Portuguese occurred towards the beginning of the second half of the 1540s and involved three different components:

1. Liberalisation of the private Portuguese trade in the Gulf of Bengal, in Southeast Asia and in the China Sea; a policy launched by the Estado da Índia under Martim Afonso de Sousa (1542-1545) ${ }^{73}$ and to a large extent continued by his successor, João de Castro (1545-1548) ${ }^{74}$;

2. Establishment of the captains of Malacca monopoly over all maritime trading voyages between the city and ports in the region, subsequently

\section{Matos (1992: 82).}

72. See the translation of this Chinese text dating from 1548 in Portugal Encontra a China. Testemunhos de uma convivência, Rui Rocha (coord.) (Lisbon/Macao: Instituto Camões/Fundação Oriente, 2005): 66.

73. "Notes sent to the King on the arrival of Martim Afonso de Sousa in India and on his government" (1544) (As Gavetas: III, 199-234 [202-203]). This makes clear how, immediately after his arrival in Goa, Governor Sousa granted at least eight voyages to China to either persons in his trust or direct family members. On Martim Afonso de Sousa, see Pelúcia (2011).

74. The voyage between India and Patani was granted to Diogo Soares de Castro who then remained in the region during three years beyond any control from the Portuguese authorities ("Notes sent to the King on the arrival of Martim Afonso de Sousa in India and on his government," 1544) (As Gavetas: III, 199-234 [202-203]). 
confirmed by Viceroy João de Castro (1545-1548) - Patani entered onto this list; ${ }^{75}$

3. Integration of Patani into the administrative structure of the Estado da Índia through the nomination of a resident Captain in $1545 .^{76}$

The first component saw the normalisation of a trend that had been deepening ever since 1533 - following the mission to Patani led by Manuel Godinho. It placed the right to grant trade voyages in the hands of the Estado da Índia leaders who then granted them to their proteges and family members, especially those travelling to the ports in south China. This liberalisation did not exclude Patani, which remained the springboard onto the Chinese markets, furthermore, probably conceding more favourable customs terms than those prevailing in Malacca and stimulating partnerships with overseas Chinese residents in the city. Patani thus strengthened its role as the incubator for Luso-Asian trade. Patani, once again, fell within the scope of a debate in Lisbon and Goa around the liberalisation of the pepper trade. According to at least three Portuguese veterans in Asian affairs, including the already known Pero de Faria, the large number of private Portuguese traders bringing pepper from Southeast Asia (Sumatra, Java, Patani, etc.) was "saturating" the Chinese market, thus drastically reducing the profit margins (by 50 to $60 \%$ ). It was furthermore impossible to compete with the Chinese traders who would annually send out 12 to 15 junks loaded with pepper from Patani to China. ${ }^{77}$ The best documented case of these private Portuguese operators is that of Diogo Soares de Castro, a personal friend of Governor Afonso de Mello who, in 1545, was able to benefit from a voyage between India and Patani. He then made Patani the base for his operations during the following three years. ${ }^{78}$

In fact, the second component was the consecration of the official policy dating back at least to the Estêvão da Gama rule of Malacca, if not earlier. This official policy reflected the level of control, verging on a monopoly, of the captains of Malacca over the private and official Portuguese trade both in Southeast Asia and from there onto China. This situation was to be repeated in

\section{Cartas Castro: III, 388.}

76. Couto: $6,1,1$.

77. Report of Pero de Faria on the pepper trade, Goa, 19/11/1545, ANTT, CC 1-77-18; Report of Duarte Barreto on the pepper trade, Goa, 6/11/1545, BA 51-VII-22, fls. 141 and after; Report of Duarte Miranda de Azevedo on the pepper trade, Goa, 27/1/1545, ANTT CC 1-77-31 (all published in Thomaz 1998).

78. Letter from Diogo Soares de Castro to D. Álvaro de Castro, Kusima, 16/11/1545, ANTT, Cartas de Goa de D. João de Castro, fl. 100; Letter from Diogo Soares de Castro to D. Álvaro de Castro, Patani, 9/10/1546, ANTT, Colecção de São Lourenço, book 4, fl. 13-13v (the only dated Portuguese letter from Patani). In this letter, Soares de Castro asked for permission to send an extra ship from Patani to Bengal, and from there to Hormuz. 
the late 1540s when the Gama family regained the captaincy of Malacca. Pedro da Silva da Gama served as the city's captain between 1548 and 1552, followed by one of his brothers, Álvaro d'Ataíde da Gama, between 1552 and $1554 .{ }^{79}$

In turn, the third component was absolutely new and reflected the incorporation of Patani into the Portuguese political-administrative framework in Asia. The nomination of Diogo Soares de Mello as the resident captain in $1545^{80}$ was an attempt by the Estado da Índia - in an apparent contradiction to the policy of liberalising private trade - to channel the payment of customs duties by Portuguese and Chinese vessels departing in the direction of China at Malacca ${ }^{81}$ The objective of the Estado da India was to drive the recovery of the commercial vitality of Malacca given that the city was unable to compete with Patani where the customs duties were lower or, as testified to by one Portuguese source, no duties at all were levied. ${ }^{82}$ Did this strategy represent a fiscal policy option chosen by the sultan, or was it a more liberal model imposed by the local mercantile elites, specifically the influential and large Chinese community? Whatever might be the case, during his stay in Patani (around twelve months), ${ }^{83}$ Captain Soares de Mello sought to cushion the impact of this new aggressive Portuguese policy by maintaining a peaceful understanding with the sultan and above all guaranteeing peace with Malacca. ${ }^{84}$

This apparently bore few lasting results. Modifications in the prevailing regional situation taking place in 1546/1547 brought about a rapid end to the official Portuguese plans for Patani. Johor's strategy designed to affirm itself as a regional political-military and economic power, and the leading heir of the Malay political tradition of Malacca led the sultanate to head a naval coalition alongside Perak and Pahang against Patani. As the Patani chronicle and the Sejarah Melayu are completely silent as regards these events, we can rely on the sole Portuguese sources. According to these sources, for reasons of "honour," Sultan Alauddin Syah of Johor (1528-1564), entered into an alliance with his brother, the Sultan of Perak, Muzzafar Syah (1528-1549), and the Sultan of Pahang, Mahmmud Syah (1540-1555). They gathered an

79. This official or officialised practice of the Estado da Índia was the subject of heated legal and theological discussions by the Company of Jesus and the Portuguese and Luso-Asian private sectors most closely connected with Southeast Asia and the China Sea in the late 1560s. The trade route via Patani did not remain beyond the scope of this discussion (Alves 2000: 180-182).

80. Soares de Mello was originally appointed by the governor Martim Afonso de Sousa but he was confirmed by Viceroy João de Castro (Couto: VI/1/1).

81. Couto: $\mathrm{VI} / 1 / 3$.

82. Couto: $\mathrm{VI} / 1 / 1 ; \mathrm{VI} / 1 / 3$.

83. Couto: $\mathrm{VI} / 5 / 1$.

84. Idem. 
armada of 300 vessels in preparation for a naval assault on Patani. ${ }^{85}$ What these Portuguese sources mean with "offenses" and "aggressions" is not easy to identify precisely but the attack on Patani by the Johor/Perak/Pahang alliance did not materialise and the armada returned to Johor for unknown reasons. ${ }^{86}$ Perhaps because Patani brought "satisfactions," thus leading to a ceasefire and peace among the parties involved. ${ }^{87}$

However, it seems difficult to separate this political-military offensive led by Johor from another undertaking headed by the Sultanate of Aceh. Sultan Alauddin Riayat Syah (1539-1571) embarked on an aggressive campaign of territorial expansionism during the same period, both in the north of Sumatra and in the Strait of Malacca. ${ }^{88}$ In 1547, Aceh launched another offensive against Malacca almost simultaneously with an attack on Perlis. Interestingly, the defeated Sultan of Perlis took refuge, perhaps via an overland route, in Patani. This decision may show that Patani was at the epicentre of important geopolitical regional readjustments. This context leads us to question whether or not it reveals a broader regional conflict extending to the major centres of production and distribution of spices and drugs in Southeast Asia, pepper in particular. This kind of "Pepper War" may also have been triggered by changes on the major consumption markets, in the Middle East, Near East and China. Hence, the expansionist strategy of Aceh may have drawn on the military and technological support as well as the political-religious approval from Istanbul. ${ }^{89}$ Indeed, three Turkish galleys along with their crews and soldiers, including members of the elite Janissary forces, took part in the 1547 siege of Malacca. ${ }^{90}$

In the face of this new situation, the Captain of Malacca, Pedro da Silva da Gama, ordered the tactical withdrawal of the Portuguese captain of Patani in order to keep their neutrality in this conflict..$^{91}$ This move also demonstrated both diplomatic and strategic vision in allowing regional powers to fight each other while Malacca remained off the list of any external attacker. ${ }^{92}$ However, the 1550s saw Malacca confronted to other challenges and changes, this time brought about by private Portuguese and Luso-Asian traders in Southeast Asia and south China. These traders were desperately attempting to establish a port

85. Couto: IV/5/1; Sousa: 355 and following; Andrada: 278. Sousa's text is published as document no. 16.

86. Couto: IV/5/1; Sousa: 356.

87. Andrada (282) is the only one to suggest such explanation, albeit without defining what he meant by "satisfactions." Might this be a formal request for apologies from the Sultan of Patani or the payment of compensation in whatever form?

88. Alves 1999: 164-169.

89. Casale (2010: 57-59; 118-121); Alves (2015).

90. Sousa: 356.

91. Couto: IV/5/1.

92. Andrada: 279. 
in China as a permanent base. Following failed attempts in Fujian and Zhejiang, their attention then turned to the coast of Guangdong. The time was about to come for Macau. It was a time of gradual establishment for private Portuguese and Luso-Asian interests in Macau, where a "Patani" existed, perhaps already for several decades. It was the "Patani" of overseas Chinese and other Asians who traded between Southeast Asia and Guangzhou. After 1555, it also became the Luso-Asian "Patani," which not only survived down the following five centuries but remains until today among the placenames of Macau.

\section{A Tale of "Two Patanis" (1555-1580)}

In the 1550s, the Portuguese plans for Southeast Asia and the China Sea, now extending to the Japanese archipelago, turned towards searching for a permanent base along the coastal zone of China. Following the setbacks, serious to a greater or lesser extent, in Fujian and Zhejiang, the province of Guangdong appeared as the last and therefore the best alternative. After Shangchuan and Langbaigang, in the Pearl River delta (Zhu Jiang), the port of Macau (Ao Men) became steadily more important from 1555 onwards and on a more secure basis after the 1560 's.

In association with Chinese overseas merchants from Southeast Asia - in the majority arriving from Patani - the private Portuguese traders founded Luso-Asian partnerships and gradually established a permanent presence in Macau that was step-by-step becoming an international trading port. In alignment with the complacency of the provincial authorities of Guangdong and the discrete permission of the Ming court, Macau slowly but securely prospered. This urbanisation process started out in an area called Colina do Patane ("Hill of Pears" in Chinese toponymy) by the Portuguese. It is certainly the oldest known Portuguese placename in Macau. Patane is located on a hill, overlooking the inner port (almost inactive today apart from a landing wharf for fishing vessels). The Patane area represented therefore a strategic location, allowing for the defence of the commercial port. In addition, it sheltered its own watercourse called Ribeira do Patane by the Portuguese. As the oldest residential area in the city, this hill became criss-crossed by an intricate network of streets, alleys and cul-de-sacs (some of them receiving the name of Patani/Patane). Patani/Patane also sheltered the oldest fortification in the city, the Forte do Patane or da Palanchica (with no surviving remains). This zone was and is still dotted with ancient altars dedicated to ancestors and other divinities of the Chinese popular religion, as much as small Chinese temples (especially the Tou Tei temple or the Pagode do Patane).

This means that Patani and its business community - mostly overseas Chinese - and their Luso-Asian trading partners, were key players at the origins of the settlement of the Portuguese in Macau by 1555/1557. Gaspar Lopes, one of these private Portuguese traders, wrote in 1551 from Southern China to advise other Portuguese traders to avoid Malacca (and the monopolistic 
appetites of the captains of the Estado da Índia) and to depart for China from Patani as "Patane is a friend until no longer able." 93 Despite occasional conflictual episodes caused by blunders from some private Portuguese operators, the ongoing relationship between Patani and the Portuguese remained stable through to the mid-1560s.${ }^{94}$ Once again, we turn to Mendes Pinto who provides an account of an incident that he witnessed in 1555 when stopping over at Patani (in order to acquire provisions) en route to Macau. $\mathrm{He}$ provides some useful information on the social and political life of Patani and its relations with the Portuguese.

Mendes Pinto mentions the presence of Cām and Minangkabau communities in Patani in addition to a significant military component. He also points out the longstanding and good personal relations with the sultan, most probably Mudhaffar Syah, to the point that he was received in a private audience in the royal palace, requesting the sultan's assistance to save the lives of several Portuguese in a commercial dispute following a revolt by the local population instigated by the Cām and Minangkabau communities. ${ }^{95}$ It makes the information provided by Pinto all the more interesting given his direct access to the palace and to the sultan at a time he was a Jesuit priest, hence perhaps dressed as a priest (and accompanied by his sexton). This episode showing religious tolerance may also convey the reality of an extreme pragmatism adopted by the Sultan of Patani as regards other religions, specifically Christianity, whenever such attitude served his own politicaldiplomatic and economic objectives.

Throughout the 1560s and 1570s, Macau - where the new "Patani" was already prospering, growing and spilling over the rest of the peninsula transformed into an international trading port. There is only very scant information on the ongoing contacts and relations between the sultanate of Patani and the Portuguese and Luso-Asians of Macau. We know the existence of direct trade between Patani and Macau but nothing as regards quantities and frequency. ${ }^{96}$ The official Portuguese trade, under the responsibility of Macau-based operators, continued through concessions and protections issued by the governors and viceroys of the Estado da Índia. In 1568, on the request

93. Letter from Gaspar Lopes to his brother, n/p (South China), 14/10/1551, Schurhammer (1964: 669-673 [672]).

94. Luís de Almeida, a Portuguese Jew, en route to China, stopped over in Patani and seized a junk belonging to the city "captain" (?), killing its crew and sinking the ship (Letter from Melchior Nunes Barreto S.J. to the Jesuits in Goa, Langbaigang, 23/11/1555, Loureiro (1996: 77-89 [79]).

95. Pinto Cartas: 63. Published as document $\mathrm{n}^{\circ} 17$.

96. Letter from Francisco Perez S.J. to Luís Gonçalves S.J., Macao, 3/12/1564, Pires (1964: 768-777 [771]). Portuguese vessels arriving in Macau from Patani brought such precious cargoes that they stimulated the activities of Chinese pirates present along the coasts of the Guangdong province. 
of Viceroy Antão de Noronha (1564-1568), the King of Portugal granted three voyages from India to Patani to his chamber-boy, Pero de Magalhães. ${ }^{97}$

The little that we do know about the Patani-Macau contacts derives from Jesuit sources and indicates that Mansur Syah (1564-1572), the new Sultan of Patani, approached Macau. If not Malacca, Macau was a natural target for his diplomacy and commercial policy. In 1568 or early 1569, Mansur Syah sent a junk loaded with pepper to Macau (in fact, to Guangzhou, via Macau) accompanied by a letter to Belchior Carneiro S.J. (1566-1583), the city's bishop. ${ }^{98}$ In this letter, Sultan Mansur Syah requested two things: the supervision of his junk and the sending of priests (Jesuits?) to Patani. ${ }^{99}$ However, more than any expression of religious tolerance or a display of ecumenism on behalf of the Sultan of Patani, this outreach initiative may be interpreted as a way to counterbalance the difficult period then experienced by the sultanate, losing population and suffering military-naval pressure from Palembang. ${ }^{100}$ Patani was perhaps hoping for military assistance from Macau given that Malacca was weakened due to the depth of its political-military and economic difficulties at the time. However, things came out differently. In 1570, on the request of the provincial authorities in Guangdong, a Macau armada, led by both Chinese and Portuguese forces (who the Chinese referred to as folangji ${ }^{101}$ ), launched a military expedition along the coastal region of Patani to attack Lin Daoquian, the famous wokou. ${ }^{102}$ Defeated, Lin took permanent residence in Patani just a few years later, opening up a cycle of very strong influence over the economic and socio-political life of the sultanate. This episode aligning Macau with the defence of the southern coastline of China, preventively carried out in Southeast Asian waters, may also

97. Summary of a letter from the King of Portugal to the Viceroy Luís de Ataíde, Almeirim, 17/3/1568, APO (V-2: 684).

98. On this bishop of Macau, see Soares (2015:39-43).

99. Letter from Cristóvão da Costa S.J. to Manuel Teixeira S.J., Malacca, 8/11/1569, DocIndica (VIII: 31-32). Father Costa even notes the expression of openness of the sultan in relation to Jesuit missionary activities in Patani. Interestingly, a few years earlier, another Jesuit mentioned the presence of Patani students at the college of the Company of Jesus in Goa (Letter from Luís Fróis S.J. to Marco Nunes S.J. in Portugal, Goa, 12(?)/12/1560, DocIndica (IV: 833-839 [836]).

100. HP $T \& W$ (1970): II, 9.

101. A term used in various Asian languages, especially in maritime Asia, from the sixteenth century onwards, to designate the Portuguese and, on occasion, Catholics in general. It derives from the Arabic ifranji/firanji or the Persian faranji, passing into the Malay language in the form of peringgi and, in turn, into Chinese as folangji.

102. Wade (2013: 69). The Chinese source cited and translated by Wade provides us with the highly valuable information that the Macau armada was led by Wu Zhang, a trader (?) from Xiangshan, the Chinese district closest to Macau, and by two Portuguese (folangji), whose names are extremely difficult to reconstruct from the phonetical spellings in Chinese but are likely to refer to the Portuguese Jewish magnate Bartolomeu Vaz Landeiro and his nephew Vicente Landeiro (Sousa 2010; Silva 2015: I: 69). 
be a consequence of a growing rivalry between the trading community from Fujian and the one from Guangdong. This rivalry between Chinese traders and consortia from these two provinces was a constant factor underlying the history of Macau throughout the sixteenth and seventeenth centuries and may also have impacted on Patani during this same period.

\section{Conquest, trade and diplomacy under the Queen's Rule (1584-1642)}

It is not possible to ascertain whether there was any awareness in Portugal, in Goa or even in Malacca as regards the political and social turbulence ongoing in the sultanate of Patani following the death of Sultan Mansur Syah in 1572. ${ }^{103}$ This situation persisted until 1584 during the reigns of Patik Siam and Sultan Bahdur Syah. ${ }^{104}$ However, the arrival in power of a woman would certainly not have gone entirely unnoticed at least in the Portuguese circles in Malacca and in Macau as this event inaugurated a truly female dynasty on the throne of Patani that began with Raja Hijau and would only come to a close over a century later. We also do not know, but it would have been difficult to occur in practice, whether or not Patani knew about the dynastic struggles ongoing in Portugal that ended up in Spanish rule under the so-called Dual Monarchy (1580-1640).

Whatever the prevailing level of knowledge, the Dual Monarchy, which strove to unite the military-naval forces of Portugal and Spain, brought about a new paradigm in the relationship between the political hierarchy of the Estado da Índia and the Portuguese Padroado and a number of regions in Asia, especially in Southeast Asia and in the China Sea. It was a moment of great plans during which Portugal could at least dream of restoring the glory, euphoria and imperial conquest of King Manuel's reign. Some of the most warring factions of the Portuguese society, whether in Portugal or in Asia, turned back to old arguments to justify preeminence of military expansionism over commercial-maritime expansion that had taken precedence during recent decades. These demands emerged in various forms and with greater or lesser levels of realism as regards the plans for regional conquest. One of the leading figures of this warring trend was João Ribeiro Gaio (1578-1601), the Bishop of Malacca, who put forward plans verging on megalomania while still remaining within the boundaries of realism. It is in this context that the Sultanate of Aceh, ${ }^{105}$ Siam and, in the case of greatest interest here, Patani were targeted in the $1580 \mathrm{~s}$.

103. $H P T \& W(1970: I, 11)$.

104. Idem.

105. Alves \& Manguin 1997. 
In his Relación de Patane/Rutter of Patani (1584) ${ }^{106}$, Bishop Ribeiro Gaio set out how his four Portuguese informers had a good knowledge of the sultanate (António Dias, Henrique Mendes, ${ }^{107}$ Francisco das Neves and João Serrão), perhaps due to their activities as traders. This rutter represents a geographic and military guide for the conquest of the sultanate by Portuguese and Spanish troops (2,000 soldiers), a formula that would again be repeated by Ribeiro Gaio in his guides to the conquest of Aceh ${ }^{108}$ and Siam. ${ }^{109}$ The detail and the updated nature of the information as regards the extent of the capital, its socio-economic livelihood and even religion (which we drew upon above) demonstrates the familiarity of at least some Portuguese with the city and its surroundings that would only have been possible with a great degree of freedom of circulation, observation and gathering of information. A feat we would today identify as genuine intelligence. The same applies to the account by Francisco de Dueñas ${ }^{110}$ a Spanish military officer, which includes interesting news on Patani, in his Relacion de algunas cosas particulares que vimos y entendimos en la ciudad de Canton / "Report on some particular things that we saw and heard in the city of Canton" (1580). Dueñas' informers were also Portuguese, but residents in Macau ${ }^{111}$ who maintained a continuous and regular presence in Patani (where they regularly delivered the much desired firearms ammunition). According to Dueñas, the merchants from Macau were permitted to remain in the city but did not have access to the royal palace, except on festive days when the sultan would invite the captains of the Portuguese ships for a banquet and play cards and chess with them. ${ }^{112}$ Dueñas, as did Ribeiro Gaio, defended the advantages of the conquest of Patani by joint Luso-Spanish forces.

106. This rutter was previously published and translated into English in Souza \& Turley eds. 2016. A new transcription of manuscript and English translation are published in this volume as document $\mathrm{n}^{\circ} 19$.

107. This Henrique Mendes may be the same as the one mentioned in 1591, an important new-Christian whose businesses in Asia drew the attention of King Filipe I of Portugal to the extent of ordering his immediate return to Portugal (Letter from Filipe I of Portugal to the Viceroy of the Estado da Índia, Lisbon, I/1591, Livro das Monções $\mathrm{n}^{\mathrm{o}}$ 3B (FU, Ficheiro 2, gaveta 1, divisões 6 e 720-23)).

108. Alves \& Manguin eds. 1997: 102.

109. Souza \& Turley eds. 2016: 500.

110. Francisco de Dueñas was one of the military figures accompanying the first missionary expeditions undertaken by the Spanish Franciscans to China in 1579. It was on this occasion that he wrote this report that we transcribe the excerpt related to Patani (see document no. 18). Francisco de Duenãs survived this expedition and returned to Manila, where he remained until at least 1583 (Ollé 2000: 96, 118).

111. In the $1580 \mathrm{~s}$, the viceroys and governors of the Estado da Índia granted a yearly trade voyage departing from Macau to Patani for a value of 1,000 cruzados, commonly sold for 300 cruzados ( $L C F$ : fl.97).

112. Dueñas: 6. Published as document no.18. 
In addition to the plans for conquest and the conquistador rhetoric, the Estado da Índia maintained the commercial route with Patani active throughout the $1580 \mathrm{~s}$. The captains of Malacca continued to have, among their various and highly contested special privileges, the right to a yearly voyage to Patani alongside the opportunity to sell this right for a maximum value of 400 cruzados. ${ }^{113}$ They also kept open the diplomatic channel with the sovereigns of Patani, dispatching missions on their behalf bearing both letters and prestigious presents designed to guarantee the supply of rice and other foodstuffs to Malacca. ${ }^{14}$

The majority of Portuguese and Luso-Asian traders and sailors engaged in business and able to move at ease in Patani certainly did not positively perceive these plans for conquest under consideration by the more hard-line factions of the Estado da Índia and the Padroado in Asia. ${ }^{15}$ Isabel Ferreira, a new Christian Portuguese woman, was among them. She ended up arrested and condemned by the Goa Inquisition in 1599. ${ }^{116}$ These Portuguese feared an escalation in the conflict between the Estado da Índia and the Sultanate of Patani.

Locally, there must have been greater fear over the dynastic change in Patani and a woman, Raja Hijau (1584-1616), ascending to the throne. Most of these Luso-Asians were resident in Malacca but also in Macau, and a number of them would reside seasonally in Patani. ${ }^{117}$ They brought to Patani cotton cloths produced in Coromandel and looked for pepper (sourced from Jambi and Indragiri in Sumatra), rice and other provisions. ${ }^{118}$ However, at the turn of the seventeenth century, gold (powder or nuggets) from the hinterland of Patani seem to be the favourite item in the markets of the city, ${ }^{119}$ among the Portuguese and Luso-Asian traders. ${ }^{120}$

113. $L C F$ : (fl. 105).

114. Coutre: 155.

115. The Padroado Real (Royal Patronage) or Padroado Ultramarino Português (Overseas Portuguese Patronage) was established through an agreement between the Vatican and Portugal, starting in the mid-fifteenth century and later confirmed in 1514. According to this agreement, the kings of Portugal were entitled to supervise and administer the Christianization of the overseas territories under their domain, and to appoint the ecclesiastical hierarchy.

116. BNP, Reservados, códice 203, fl. 409.

117. Many of these Portuguese and Luso-Asians owned slaves who were locals from Patani, some gentiles (Chinese?) and other Muslims. Between 1580 and 1602, there are at least four cases, all of them subject to processes of the Goa Index (BNP, Reservados, códice 203, fls. 366v, 410, 498 e. 555v).

118. Coutre: $154-155$.

119. Erédia: 77.

120. Lobato 1999: 279-280. 
Furthermore, the risks posed by Raja Hijau taking power did not seem to have been so great especially because this period of female rule of the sultanate would seem to have corresponded to a more liberal policy under the significant political and socio-economic influence of the orang kaya. ${ }^{121}$ The new and looming threat was now the Dutch company (which opened a factory there in 1602) and eventually other European powers such as the English (factory opened in 1612) and the French. The arrival in the region of European rivals, able to operate on a far larger financial and commercial scale, led to a spiralling in the disputes (over the best prices, the primacy in access both to the goods and the main commercial markets, houses in the city), as well as competition for the tolerance or even the protection of the sultan and senior dignitaries of the sultanate. ${ }^{122}$ Perhaps because of this greater instability and competition, some Portuguese visitors or residents, opted to maintain their own security through employing a personal guard composed of Japanese mercenaries. ${ }^{123}$

The alterations in the economic geography of the Strait of Malacca and Sunda (and in maritime Southeast Asia in general), the impact of the competition with the Dutch and other Europeans rivals, as well as the redefinition of the priority markets for Portuguese and Luso-Asian traders (and, on a lesser scale, the Estado da Índia), may have been the reasons behind Patani all but disappearing from Portuguese documents during most of the early years of the seventeenth century. An exception is the "Santo António affair" (1605), triggered by Raja Hijau ordering the seizure in Patani (in accordance with the Dutch) of this vessel and its extremely valuable cargo (silk, Chinese porcelain and Japanese silver) on its way from Macau to Malacca. ${ }^{124}$ This decision understandably caused tension between Patani and Malacca as conveyed by some Portuguese and Dutch sources. However, in general, both to the queen and to the local elites (orang kaya and the large Chinese community), trade with the Portuguese did not seem to hold any particular interest. Many of these overseas Chinese traders had already opted to give up on Malacca for the purpose of acquiring pepper, preferring instead to visit Patani, Pahang, Indragiri and Jambi. ${ }^{125}$ In a few cases, the Portuguese of Malacca represented a threat to their interests and commercial-maritime investments. For example, in 1615, a junk owned by Raja Hijau was seized in Malacca together with its entire cargo ${ }^{126}$ following a spark in the ongoing naval

121. Perret 2004: 227-229.

122. Coutre: $155-160$.

123. Coutre: 161.

124. On this event, see Borschberg (2002). For a general vision, with details on Patani and the Luso-Dutch rivalry in Southeast Asia in the early decades of the seventeenth century, see Murteira (2012).

125. Letter from the King of Portugal to Manuel de Sousa Coutinho, Governor of the Estado da Índia, Lisbon, 6/1/1591, AHU, cod. 281, fl. 141v.

126. Letter from the King of Portugal to Jerónimo de Azevedo, Viceroy of the Estado 
conflict between the Portuguese and the Patani ruler. This event led to the seizure of at least one Portuguese vessel arriving from Macau in Patani that same year $1615 .{ }^{127}$ The Estado da Índia then decided to engage in a punitive military policy and with apparently heavy consequences for Patani. ${ }^{128}$ They led Raja Hijau to call for a ceasefire with Malacca, reaffirming her sincerity despite having at the same time welcomed European factories into her port as well as European capital. ${ }^{129}$ These fluctuations in the relationship between Patani and the Portuguese even led the Estado da Índia, on the occasion of the arrival of an embassy from the Siamese King Sanpet III in 1616, to include relations with Patani on the agenda for discussion. ${ }^{130}$ During these negotiations in Goa, Sanpet III's ambassador brought the news of Raja Hijau's death (which confirms the widely accepted chronology). He depicted her as "insane" and assured that Siam had already "substituted" her with a new and "more balanced" queen (Raja Biru), able at resuming good political and commercial relations between Patani and Malacca. ${ }^{131}$ This statement coming from the Siamese ambassador tells a lot about the strong level of Siam intervention in the political and dynastic affairs of Patani during this period. Raja Biru was already the ruler when the Estado da Índia confirmed the signing of a peace agreement between Patani and the captain of Malacca. ${ }^{132}$ This agreement was signed before April 1619, if not by late $1618^{133}$ and it's an interesting piece of Euro-Asian diplomatic rhetoric. These are its most politically significant points: a) Raja Biru justifies the acceptance of Dutch and English trade in Patani with the example of Siam (a "friend" of the Portuguese), who had already accepted the Dutch and the English in Ayutthaya, dully informing the King of Portugal; b) Patani and Portuguese Malacca strengthen their defensive alliance against a possible Acehnese attack; c) Malacca is called to mediate a future peace agreement between Patani and Johor. ${ }^{134}$ These three points of the

da Índia, Lisbon, 15/3/1616, DRI/LM (IX: 493).

127. Letter from João Caiado de Gamboa, former Captain of Malacca, n/l, n/d (post1630), BA 50-V-34, fl. 172v.

128. Idem.

129. Idem.

130. Faria e Sousa: IV, 101.

131. Idem.

132. Warrant from the Viceroy of the Estado da Índia, Goa, 20/4/1619, APO (VI, 1175), published as document no.22.

133. A copy of this 9 articles' treaty between Malacca and Patani was first transcribed and published by Pissurlencar (1953-1957: I, 42-44), and is published and translated here as document 21.

134. In exchange for the political and military alliance with Malacca, Patani commited itself to send every monsoon foodstuff to the Portuguese (rice and all sorts of meat). No reference is made to pepper or gold. Does this suggest that pepper trade was in decline in Patani, by the late 1610s, or does it simply confirm the decline of Malacca 
1618/1619 peace agreement highlight the diplomatic cunning of Patani's ruler, and her sharp awareness of the winds of change, and indeed of rapid change, blowing through the geopolitical complex of the Straits of Malacca. In fact, the Sultanate of Aceh, under the muscular leadership of Sultan Iskandar Muda (1607-1636), embarked on an ambitious expansionist strategy that also extended to the trade in pepper between both sides of the Strait.

The conquests made by Aceh followed upon each other at a very rapid rate, similar to a blitzkrieg. The conquests of Deli and Aru, in Sumatra (in 1612 and 1613), were followed by attacks on Johor in 1613 and 1615, Pahang in 1617 and 1618 (and, once again, in 1635). Soon thereafter, Aceh attacked Kedah in 1619 and $1620,{ }^{135}$ and Perak in 1620 . This attack on Perak was exactly the reason which brought Patani into the regional geostrategic equation and in turn involved the Portuguese. In September 1620, Sultan Mansur Syah II (1619-1627) of Perak, allied to the Portuguese of Malacca, was forced to flee his country and attempted to take refuge in Patani. ${ }^{136}$ Whether or not Aceh retaliated against Patani at least prior to the major naval combat engaged in by the two sultanates in $1626,{ }^{137}$ is unknown.

With the decline of its maritime trade over the course of the 1630s, as suggested in the historiography of the sultanate, Patani would also seem to have cooled its relations with the Portuguese. Malacca itself was on the verge of conquest by Aceh as a result of the bitter and very determined siege laid by Iskandar Muda in 1629. However, it was precisely during this siege that, on the request of Pinto da Fonseca, the Captain of Malacca, the Patani ruler (perhaps already Raja Ungu) joined forces with the Sultan of Johor, Abdul Jalil Syah III (1623-1677), and his nephew to provide military support against Aceh. ${ }^{138}$ The Patani ruler deployed a fleet of 100 sails $^{139}$ to Malacca which turned out to be decisive in the victory of the Portuguese over the Aceh forces as witnessed in some of the Portuguese historical sources almost contemporary to these events. ${ }^{140}$

The gradual awareness about the shaky and uncertain situation faced by Malacca, despite the victory in 1629 , forced a rethinking of the model for the Portuguese presence not only in the Strait of Malacca but also in Southeast Asia in general. The new circumstances required political-administrative and economic reforms of the Estado da Índia. This turning point coincided with the arrival

as a spice international trading port?

135. Alves 2000: 104.

136. Letter from António Pinto da Fonseca, captain of Malacca, to the King of Portugal, Malacca, 28/11/1620, DRI/LM (VIII:393-394).

137. Perret 2004: 230, note 30 .

138. Letter (copy) from the António Pinto da Fonseca, captain of Malacca, to the Count of Linhares, Viceroy of the Estado da Índia, Malacca, 11/1/1630, BA, 51-VII-12, fl. 6v.

139. Idem, fl. $7 \mathrm{v}$.

140. Boxer 1990: 105-121. 
in Goa of Viceroy Miguel de Noronha, the Count of Linhares (1629-1635). ${ }^{141}$ Linhares'action, while governing the Estado da Índia, strongly characterised by reformist policies, represented a palpable change in the conduct of international trade. ${ }^{142} \mathrm{He}$ undertook a wide-reaching, multi-faceted and multi-directional diplomatic offensive but above all targeted the two central axes of maritime Southeast Asia; the Strait of Malacca and Sunda. Among the core objectives of this new diplomatic geography of the Estado da Índia was the securing of either the good will or the active collaboration of the Malay powers for the survival of Malacca under Portuguese rule, whether from the commercial or the military point of view or even, and even more prosaically, the supplying and reinforcing of the Portuguese positions in Makassar and Solor.

The design of this new diplomatic geography of the Estado da Índia, on the watch of Viceroy Linhares, included approaching or re-approaching, according to the respective cases, of the rulers of Aceh, Jambi, Palembang, Perak, Johor, Patani, Makassar, Banten and the Javanese empire of Mataram. ${ }^{143}$ Linhares knew well how to skillfully deploy the argument that the Estado da Índia was an "old acquaintance," as he himself expressed it, to all these sultanates of maritime Southeast Asia, boosting the "credit and reputation of the State, which is how Empires and Powers sustain themselves." As early as June 1631, an embassy from Malacca was dispatched to the Patani ruler (still Raja Ungu or already Raja Kuning?), with a letter and gifts from Linhares. ${ }^{144}$ This embassy reopened the official diplomatic channel between Patani and the Portuguese and guaranteed a renewed alliance that included the Sultan of Johor and Pahang, who remained in exile in Patani. This alliance remained active between 1633 and 1636 and, on various occasions, the Portuguese of Malacca both exchanged diplomatic missions, ${ }^{145}$ or provided naval military assistance, to Patani, firstly, against the neighbouring power of Songhkla ${ }^{146}$ in 1633, and then during the siege of Patani by the Siamese in $1634 .{ }^{147}$ We do not

141. There is a lack of any political biography of Linhares, a veteran of Portuguese overseas administration in the north of Africa and Asia. However, Anthony Disney (1981, 1991) has been the author able to provide the greatest contribution towards knowledge about his actions as viceroy of the Estado da India. We thank João Paulo Salvado for several enlightening discussions about the life and career of Miguel de Noronha.

142. For some indications on the thinking and political actions of Count Linhares as regards the Asian states with which the Estado da India maintained diplomatic relations, see Saldanha (1997).

143. Alves 2013: 81-100.

144. Letter of services of Manuel de Araújo de Azevedo, AHU, codex 501, fl. 71.

145. Letter of services of Domingos Moreno, AHU, codex 501, fl. 15.

146. Letter of services of Miguel Quinteiro Coelho, Goa, 19/6/1648, AHU, codex 445 , fl. $79 \mathrm{v}$.

147. Letter of services of Manuel de Araújo de Azevedo, AHU, codex 501, fl. 72. 
know the role played in this relationship between Patani and the Portuguese by the all-powerful bendahara Sri Paduka, of Javanese origin, who seems to have dominated the political-economic life of the sultanate at the time. ${ }^{148}$ However, we do know that, around 1635, the Portuguese remained extremely attentive to events in the region, especially the conflicting triangular relationship between Aceh (during the final days of the Iskandar Muda's reign), Johor/ Pahang and Patani. At the end of this same year, Aceh attempted yet another naval offensive against Johor/Pahang and Patani and managed to conquer both sultanates before the end of year. Both brothers, Raja Kuning and Sultan Abdul Jalil Syah fled and sought refuge in Malacca under the Portuguese. At the beginning of 1636, Viceroy Pedro da Silva (1635-1639), the successor of Linhares, wrote to King Filipe III of Portugal (1621-1640) informing him of the exile of the two brother sultans in Malacca and of the request made in writing (on 6 December 1635) for assistance in recovering their states. ${ }^{149} \mathrm{King}$ Filipe III provided a swift response to this request from Johor/Pahang and Patani. ${ }^{150}$ The answer, however, was merely an exercise in diplomatic courtesy. The Estado da Índia was busy with far more pressing priorities in other parts of the Indian Ocean with Malacca living out its final years under Portuguese rule. Furthermore, even in Europe, the period of the Dual Monarchy (PortugalSpain) was lurching towards its own end in 1640.

The destiny of the relations between Patani and the Portuguese depended on too many regional and international variables. Times had changed and, as the King of Portugal stated, little more might be done than express "displeasure" at the most recent events in the sultanate.

148. Perret 2004: 235.

149. Letter from Pedro da Silva, vice-Roy of the Estado da Índia to the King of Portugal, Goa, 8/3/1636, ANTT, Monções, nº33, fls. 250v-251.Published as document no. 24 .

150. Letter from Filipe III, king of Portugal to the Sultanah of Patani, Lisbon, 31/3/1637, ANTT, Monções nº 39, fl, 41. Published as document no. 25. 
